\title{
PERBANDINGAN KINERJA TEORITIS AIR BLAST FREEZER MENGGUNAKAN REFRIGERAN HIDROFLUOROKARBON DAN HIDROKARBON
}

\author{
Yohanes Viva Servianus, Matheus M. Dwinanto, Muhamad Jafri
}

\author{
Program Studi Teknik Mesin, Fakultas Sains dan Teknik, Universitas Nusa Cendana \\ Jl. Adi Sucipto, Penfui, Kupang, Nusa Tenggara Timur \\ yoh.servianus@gmail.com
}

\begin{abstract}
Abstrak
Air blast freezer telah digunakan sebagai cara pembekuan cepat di unit pengolahan ikan sebelum dibekukan untuk waktu yang lama di dalam cold storage. Untuk itu penggunaan refrigeran hidrokarbon yang lebih ramah lingkungan telah menjadi tuntutan dan isu sentral pada masa yang akan datang. Makalah ini menyajikan studi kinerja teoritis penggunaan R290 dan R600a sebagai pengganti R404A dan R507A. Kinerja teoritis sistem didasarkan pada variasi temperatur evaporasi menggunakan perangkat lunak CoolPack dengan temperatur kondensasi dipertahankan konstan. Besaran-besaran penting yang dianalisis adalah laju aliran massa, rasio tekanan, temperatur keluar kompresor, pelepasan kalor, konsumsi daya, koefisien kinerja, efisiensi refrigerasi, dan konsumsi energi. Hasilnya menunjukkan bahwa pada temperatur evaporator minimum, kinerja sistem yang menggunakan R290 dan R600a rata-rata lebih tinggi $\pm 14 \%$ dibandingkan dengan R404A dan R507A. R290 memiliki karakteristik yang lebih dekat pada R404A dan R507A sehingga lebih sesuai menggantikan kedua refrigeran tersebut dibandingkan dengan R600a. Namun, ini adalah analisis teoritis sistem yang dapat mengarah pada kinerja yang lebih tinggi daripada kondisi normal.
\end{abstract}

Kata kunci: air blast freezer, kinerja, refrigerasi, hidrofluorokarbon, hidrokarbon

\begin{abstract}
The air blast freezer has been used as a freezing method in fish processing units before being frozen for a long time in cold storage. For this reason, the use of hydrocarbon refrigerants that are more environmental friendly has become a demand and a central issue in the future. This paper presents a theoretical performance study of the use of R290 and R600a as a drop-in replacement to R404A and R507A. The theoretical performance of the system is based on the evaporation temperature variation using CoolPack software with the condensation temperature maintained constant. The important quantities analyzed are mass flow rate, pressure ratio, temperature discharge, heat rejected, power consumption, coefficient of performance, refrigeration efficiency, and energy consumption. The results show that at minimum evaporation temperature, system performance using R290 and $\mathrm{R} 600 \mathrm{a}$ is on average $\pm 14 \%$ higher compared to R404A and R507A. R290 has characteristics that are closer to R404A and R507A so it is more suitable to replace the two refrigerants compared to R600a. However, this is a theoretical analysis of the system which can lead to higher performance than normal conditions.
\end{abstract}

Keywords: air blast freezer, performance, refrigeration, hydrofluorocarbon, hydrocarbon

\section{PENDAHULUAN}

Unit Pengolahan Ikan (UPI) DKP Kupang merupakan tempat aktifitas pengolahan ikan yang dilengkapi dengan refrigerator untuk menghasilkan produk pengolahan ikan beku maupun segar, sehingga harus dilengkapi dengan fasilitas pengolahan, pembekuan, dan penyimpanan beku (cold storage) bertemperatur ruang $-25^{\circ} \mathrm{C}$. Ikan yang akan disimpan dalam cold storage untuk jangka waktu lama, terlebih dahulu harus dibekukan dalam ruang pembekuan cepat agar temperatur pusat ikan mencapai $-18^{\circ} \mathrm{C}$ dalam waktu yang tidak terlalu lama. Metode pembekuan cepat yang umum digunakan adalah Air Blast Freezer (ABF). Dalam $\mathrm{ABF}$ produk ikan dibekukan dengan pendinginan cepat selama rentan waktu 8 jam/shift [1]. 
ABF menggunakan refrigerasi kompresi uap untuk mencapai proses pembekuan dengan fluida kerja adalah R404A atau R507A yang merupakan refrigeran dari golongan hidroflourokarbon. Refrigeran ini tidak mengandung chlorine sehingga tidak merusak lapisan ozon tetapi masih memiliki potensi pemanasan global yang tinggi. Oleh karena itu, pada masa yang akan datang perlu digunakan refrigeran yang memiliki GWP jauh lebih rendah, yaitu dari golongan hidrokarbon seperti R290 dan R600a. Saat ini, kedua jenis refrigeran tersebut mulai digunakan di sistem refrigerasi rumah tangga, dan pengkondisian udara. Tabel 1 menyajikan sifat-sifat dan efek terhadap lingkungan dari R404A, R290, dan R600a [2], [3].

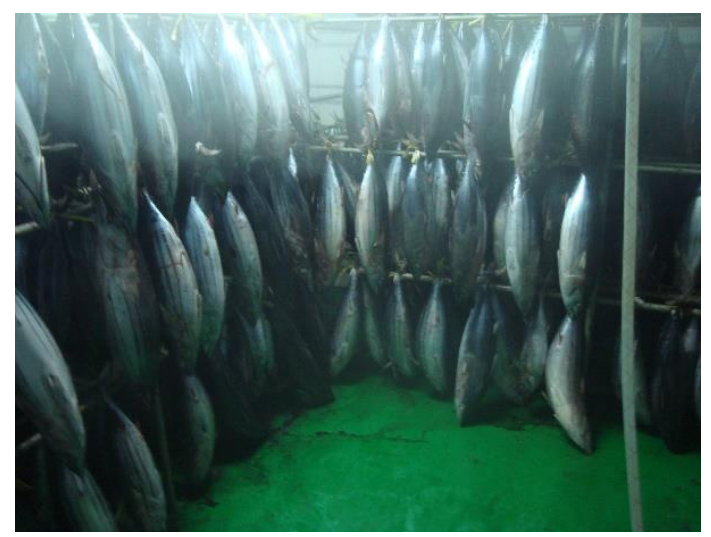

Gambar 1 Air blast freezer tipe batch

Tabel 1 Efek refrigeraan terhadap lingkungan[2][3]

\begin{tabular}{llll} 
Refrigeran & ODP & GWP & $\begin{array}{l}\text { Tingkat } \\
\text { Keamanan } \\
\text { (ASHRAE) }\end{array}$ \\
\hline R404A & 0 & 3922 & A1 \\
R507A & 0 & 3985 & A1 \\
R290 & 0 & 3 & A3 \\
R600a & 0 & 3 & A3 \\
\hline
\end{tabular}

Kinerja termodinamika ABF sangat dipengaruhi oleh refrigeran yang digunakan sebagai fluida kerja karena terdapat beda temperatur yang terbatas antara sistem dan lingkungannya, di mana ini merupakan sumber utama ireversibilitas sistem refrigerasi. Penurunan temperatur evaporasi akan mengakibatkan penurunan kinerja dan efisiensi system, begitupun sebaliknya [4], [5]. Hal ini mendorong beberapa peneliti melakukan studi teoritis dan ekperimen penggunaan refrigeran hidrokarbon terhadap kinerja sistem refrigerasi, diantaranya membandingkan kinerja energi dan exergy siklus refrigerasi kompresi uap yang menggunakan R404A, R290, dan R744. Hasil studi ini menunjukkan pada berbagai variasi temperatur evaporasi dan kondensasi, R290 memiliki kinerja yang lebih baik daripada R404A, dan R744 [6].

Penggunaan R290, R600a, dan R1270 sebagai alternatif pengganti R22 di sistem refrigerasi yang menggunakan penukar kalor subcooling terhadap kinerja teoritis juga telah dilakukan. Hasil studi ini menunjukkan bahwa sifat termodinamika R290 dan R1270 cocok dengan R22, dan menunjukkan kinerja yang lebih baik daripada R22. R600a memiliki kinerja sedikit lebih baik dalam hal daya per ton refrigerasi yang lebih rendah, dan COP yang lebih tinggi tetapi tekanan saturasi dan volume spesifiknya menyimpang secara signifikan dari R22 sehingga membutuhkan desain ulang sistem sebelum digunakan sebagai pengganti R22 [7]. Studi eksperimental penggunaan R600a dan R436A (campuran 45\% R600a dan 56\%R290) sebagai pengganti R134a di refrigerator rumah tangga juga telah dilakukan untuk membandingkan efisiensi energi dari penggunaan ketiga refrigeran tersebut. Hasilnya menunjukkan R600a memiliki efisiensi energi terbesar dibandingkan dengan dua refrigeran lainnya pada berbagai kondisi operasi [8].

Perangkat lunak CoolPack telah digunakan untuk menganalisis penggunaan tujuh refrigeran diantaranya R404A, R290, dan R600a sebagai alternatif pengganti R22. Hasil simulasi menunjukkan bahwa R290 dan R600a menghasilkan laju aliran massa terkecil sedangkan R404A adalah yang terbesar sehingga konsumsi dayanya paling besar dari semua refrigeran. Secara umum R600a memiliki kinerja tertinggi dibandingkan semua refrigeran yang ditinjau [9]. Efektivitas penukar kalor liquid suction dalam sistem refrigerasi yang menggunakan R22, R404A, dan campuran R290/R600a (50:50) juga telah diteliti secara eksperimen untuk menganalisis pengaruhnya terhadap kinerja cold storage. Hasilnya menunjukkan bahwa dalam keadaan stedi sistem yang menggunakan campuran R290/R600a memiliki kinerja yang lebih baik dari kedua refrigeran lainnya, dan memiliki karakteristik yang sama dengan R404A sehingga dapat digunakan sebagai pengganti R22 dan R404A [10]. Makalah ini menbahas analisis termodinamika penggunaan dua refrigeran hidrokarbon yaitu R290 dan R600a sebagai pengganti R404A dan R507A di ABF ketika diapliasikan di air blast freezer pada masa yang akan datang.

\section{METODE PENELITIAN}

Studi ini menggunakan perangkat lunak CoolPack versi 1.50 yang dapat mensimulasikan dengan baik analisis siklus, perhitungan dimensi sistem, perhitungan kondisi operasi, evaluasi efisiensi sistem dan komponen serta simulasi 
transien sistem. CoolPack berisi kumpulan program simulasi yang mudah digunakan dan kuat secara numerik [11].

Dalam refrigerator kompresi uap sederhana, uap refrigeran diasumsikan memasuki kompresor sebagai uap jenuh, dan cairan refrigeran sebelum memasuki katup ekspansi diasumsikan sebagai cairan jenuh. Jika dimensi evaporator sedikit diperbesar maka uap jenuh biasanya akan terus menyerap kalor, dan karenanya menjadi uap superheated sebelum mencapai kompresor. Dalam praktiknya, ini dikendalikan oleh katup ekspansi. Jika dimensi kondensor sedikit diperbesar maka cairan jenuh akan terus melepaskan kalor, dan menjadi cairan subcooled sebelum memasuki katup ekspansi (Gambar 2). Superheating dan subcooling diterapkan untuk meningkatkan efisiensi sistem [12].

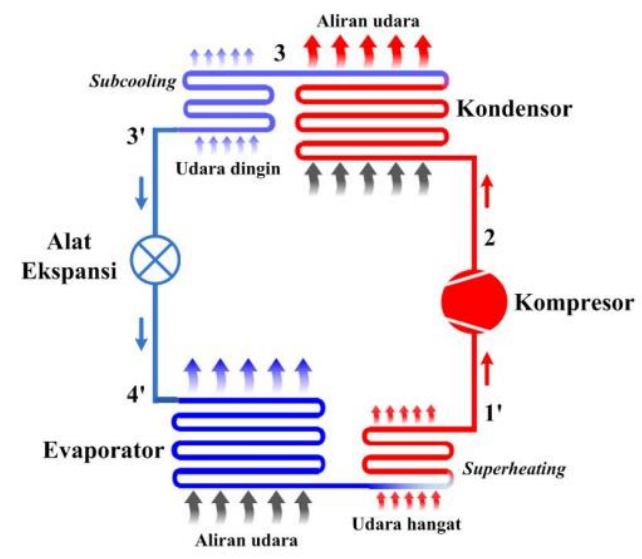

\section{Gambar 2 Skematik refrigerator kompresi uap dengan subcooling dan superheating}

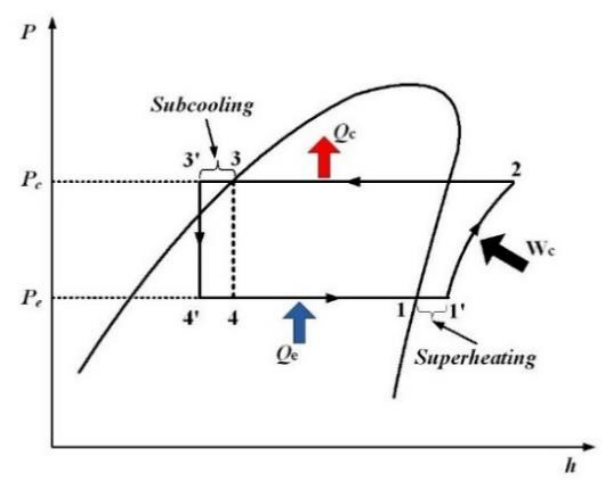

Gambar 3 Diagram $P-h$

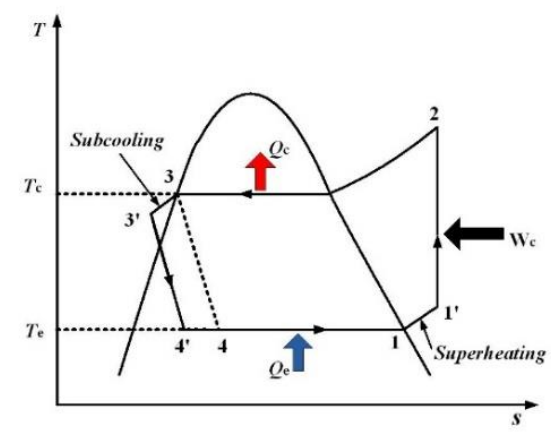

Gambar 4 Diagram $T-s$

Gambar 3 dan 4 menyajikan perbandingan diagram P-h dan T-s untuk siklus kompresi uap dengan subcooling dan superheating (1'-2-3'-4'-1') dan siklus kompresi uap jenuh (1-2-3-4-1). Kapasitas pendinginan per unit massa lebih besar untuk siklus subcooled dan superheated sehingga laju aliran massa refrigeran per unit kapasitas lebih kecil untuk siklus tersebut daripada siklus jenuh. Disamping itu, peningkatan kapasitas pendinginan secara proporsional lebih besar daripada peningkatan kalor kompresi, sehingga COP siklus subcooled dan superheated lebih tinggi daripada siklus jenuh.

Dari Gambar 3 dan 4 dapat ditentukan laju aliran massa refrigeran dengan menggunakan persamaan:

$$
n \&=\frac{Q_{e}}{h_{1^{\prime}}-h_{4^{\prime}}}
$$

dengan $Q_{e}$ adalah kapasitas pendinginan. Kalor yang dilepaskan selama proses kondensasi adalah:

$$
Q_{c}=\operatorname{nk}\left(h_{2}-h_{3^{\prime}}\right)
$$

maka kerja kompresi dapat ditentukan dari:

$$
W_{C}=Q_{c}-Q_{e}
$$

Kapasitas subcooling dan superheating dapat ditentukan dari persamaan:

$$
\begin{aligned}
& Q_{S C}=n \& \varepsilon\left(h_{3}-h_{3^{\prime}}\right) \\
& Q_{S H}=n \&\left(h_{1},-h_{1}\right) .
\end{aligned}
$$

Koefisien kinerja sistem merupakan rasio kapasitas pendinginan terhadap kerja kompresor, yang dihitung menggunakan persamaan:

$$
C O P=\frac{h_{1^{\prime}}-h_{4^{\prime}}}{h_{2}-h_{1}}
$$

dan dengan menerapkan hukum kedua termodinamika pada sistem yang dikaji maka efisiensi refrigerasi adalah: 


$$
\eta_{R}=\frac{C O P}{(C O P)_{\text {rev }}}=\frac{C O P\left(T_{3^{\prime}}-T_{1^{\prime}}\right)}{T_{1^{\prime}}}
$$

Konsumsi energi sistem selama satu tahun pengoperasian dapat ditentukan dengan persamaan:

Konsumsi energi/tahun $=\mathrm{WC} \times 8760$

Beberapa parameter dan asumsi dalam studi ini disajikan pada Tabel 2 yang dipilih berdasarkan rentang kerja dari BABF di UPI DKP Kupang.

Tabel 2 Parameter penelitian dan asumsi

\begin{tabular}{lll}
\hline Parameter & Satuan & Nilai \\
\hline Kapasitas pendinginan & $\mathrm{kW}$ & 26,79 \\
Temperatur evaporasi & ${ }^{\circ} \mathrm{C}$ & $-30-0$ \\
Temperatur kondensasi & ${ }^{\circ} \mathrm{C}$ & 40 \\
Temperatur subcooling & ${ }^{\circ} \mathrm{C}$ & 2 \\
Temperatur superheating & ${ }^{\circ} \mathrm{C}$ & 8 \\
Efisiensi isentropik & - & 0,8 \\
Efisiensi volumetrik & - & 0,8 \\
Rugi kalor kompresor & $\%$ & 10 \\
\hline
\end{tabular}

\section{HASIL DAN PEMBAHASAN}

Gambar 4 menyajikan hubungan antara variasi temperatur evaporasi terhadap laju aliran massa refrigeran untuk kapasitas pendinginan, dan temperatur kondensasi dipertahankan konstan. Terlihat bahwa laju aliran massa refrigeran yang menggunakan R290 dan R600a masing-nasingnya lebih rendah $\pm 59,45 \%$ dan $56 \%$ dibandingkan dengan penggunaan R404A. Hal ini disebabkan oleh densitas R290 dan R600a pada setiap tingkat keadaan jauh lebih rendah. Namun, densitas yang rendah akan mengakibatkan laju aliran volume refrigeran yang lebih tinggi sehingga berdampak pada peningkatan ukuran penukar kalor (kondensor dan evaporator) untuk membatasi penurunan tekanan.

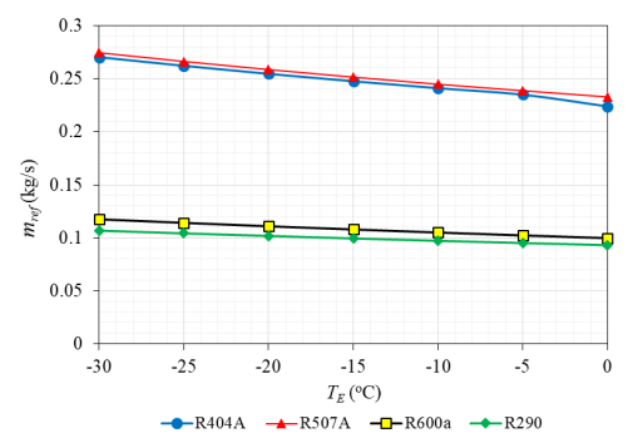

Gambar 5 Temperatur evaporasi vs laju aliran massa refrigeran

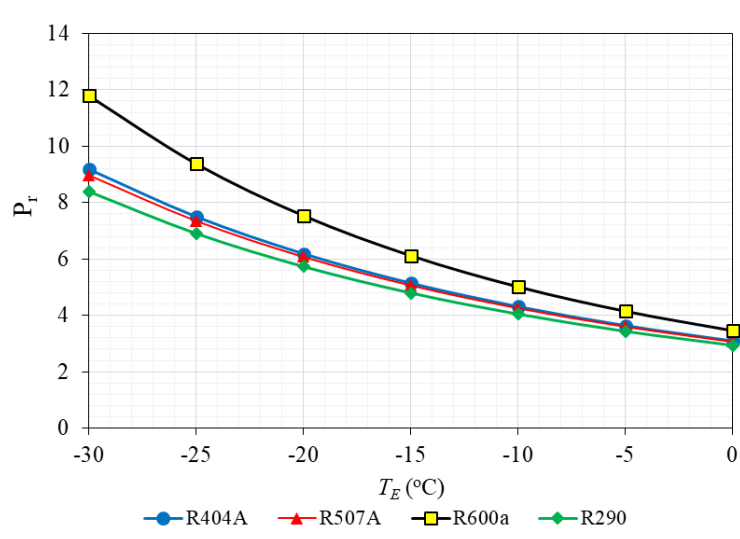

\section{Gambar 6 Temperatur evaporasi vs rasio tekanan kompresor}

Selama proses pendinginan berlangsung, penurunan temperatur evaporasi akan mengakibatkan rasio tekanan di kompresor meningkat, begitupun sebaliknya. $\mathrm{Hal}$ ini ditunjukkan pada Gambar 5, dan ini terjadi untuk semua refrigeran yang ditinjau. Rasio tekanan R290 adalah yang paling rendah di mana pada temperatur evaporasi minimum, rasio tekanannya lebih rendah masing-masingnya $\pm 8,6 \%$ dan $\pm 6,41 \%$ bila dibandingkan dengan penggunaan R404A, dan R507A serta lebih rendah $\pm 28,8 \%$ dibandingkan R600a.

Temperatur gas refrigeran keluar kompresor adalah salah satu parameter penting dalam memilih refrigeran alternatif. Temperatur keluar kompresor yang lebih rendah akan meningkatkan umur pakai kompresor karena stabilitas refrigeran dan pelumasan yang lebih baik. Pada Gambar 6 temperatur gas refrigeran keluar kompresor untuk sistem dengan R600a jauh lebih rendah dibandingkan dengan R290, R404A, dan R507A. R290 memiliki temperatur keluar kompresor yang tidak jauh berbeda dengan R404A dan R507A.

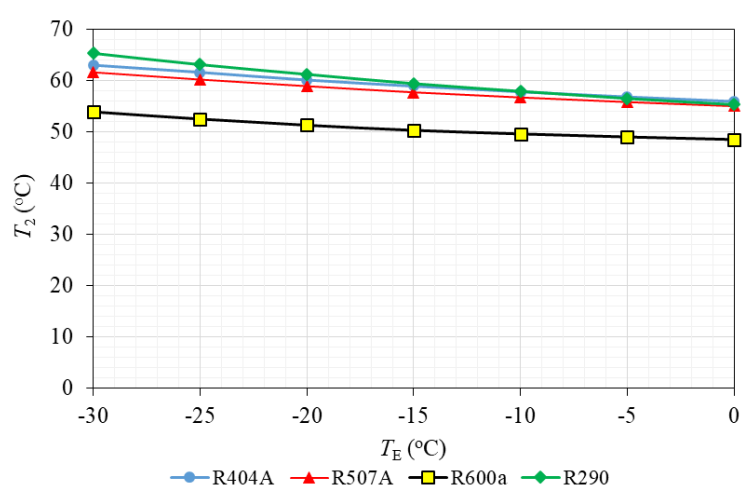

Gambar 7 Temperatur evaporasi vs temperatur gas refrigeran keluar kompresor 


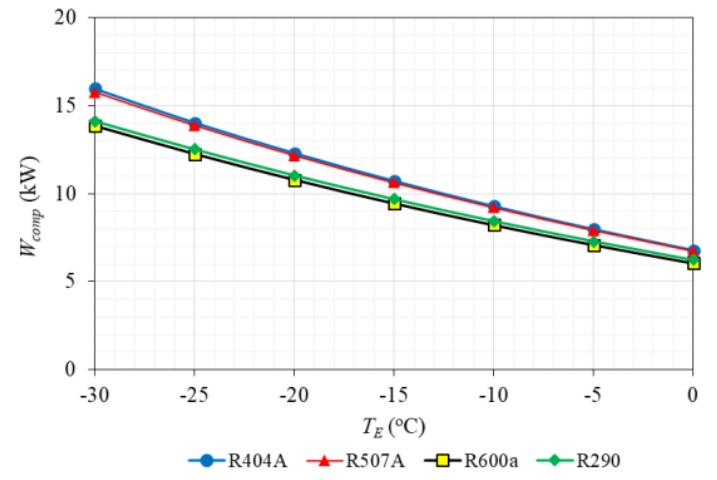
Gambar 8 Temperatur evaporasi vs daya
kompresor

Peningkatan rasio tekanan di kompresor akan berdampak pada kenaikan daya kompresor untuk setiap penurunan temperatur evaporasi, begitupun sebaliknya, dan ini ditunjukkan pada Gambar 7. Pada temperatur evaporasi minimum, daya kompresor sistem yang menggunakan R404A dan R507A relatif sama besar. Namun, penggunaan R290 nilainya rata-rata lebih kecil $\pm 10,97 \%$ bila dibandingkan dengan yang menggunakan R404A dan R507A, dan penggunaan R600a lebih kecil $\pm 12,61 \%$. Daya kompresor merupakan masukan energi terbesar yang dibutuhkan untuk mensirkulasikan sejumlah tertentu massa refrigeran sehingga proses penyerapan kalor di evaporator dan pelepasan kalor di kondensor dapat berlangsung dalam sistem.

Gambar 8 menyajikan hubungan antara temperatur evaporasi terhadap laju pelepasan kalor di kondensor. Nilai pelepasan kalor diperlukan untuk merancang kondensor, dan menghitung besarnya aliran fluida pendingin kondensor. Gambar tersebut menunjukkan bahwa meningkatnya temperatur evaporasi maka laju pelepasan kalor di kondensor akan menurun, begitupun sebaliknya. Pada temperatur evaporasi minimum, pelepasan kalor untuk sistem yang menggunakan R600a dan R290 masing-masingnya rata-rata lebih kecil $\pm 4,6 \%$ dibandingkan dengan sistem yang menggunakan R404A dan R507A.

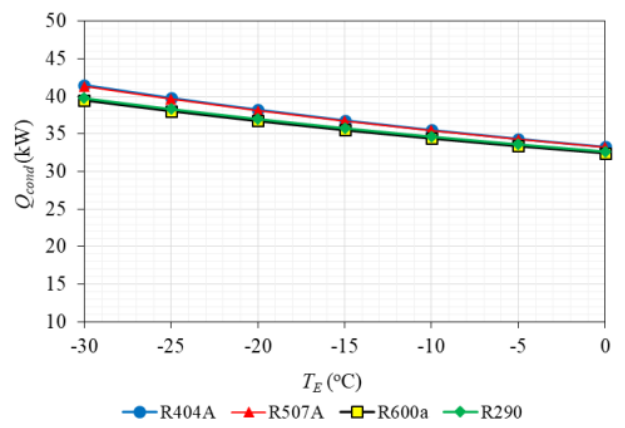

Gambar 9Temperatur evaporasi vs pelepasan kalor di kondensor

5 Servianus, Yohanes Viva., dkk; Perbandingan Kinerja Teoritis Air Blast Freezer Menggunakan Refrigeran Hidrofluorokarbon Dan Hidrokarbon
Gambar 9 menyajikan hubungan antara temperatur evaporasi dengan koefisien kinerja (COP). Dalam gambar ini terlihat bahwa dengan menurunnya temperatur evaporasi maka koefisien kinerja sistem juga akan menurun, begitupun sebaliknya. Sistem yang menggunakan R404A, dan R507A pada temperatur evaporasi minimum memiliki COP yang sama besar, dan nilainya lebih kecil dari R290 dan R600a masing-masingnya $\pm 12,31 \%$ dan $\pm 14,39 \%$. Temperatur evaporasi memiliki pengaruh yang kuat terhadap kinerja sistem refrigerasi.

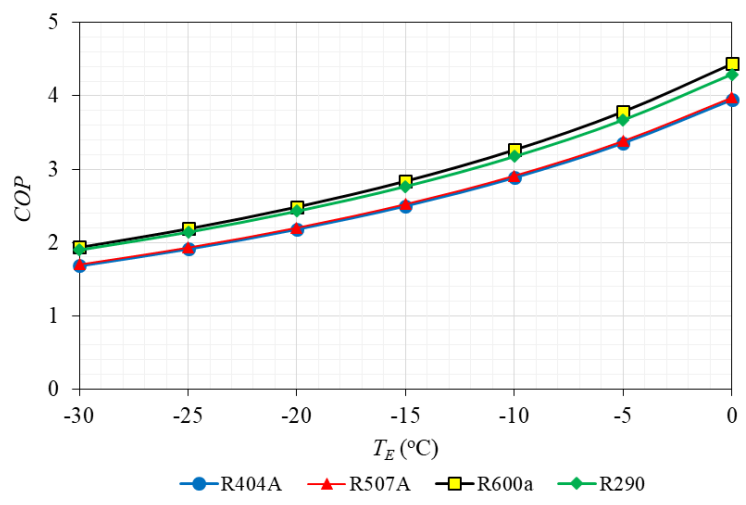

\section{Gambar 10 Temperatur evaporasi vs koefisien kinerja}

Sama halnya dengan koefisien kinerja, efisiensi refrigerasi juga akan menurun dengan menurunnya temperatur evaporasi, seperti yang ditunjukkan pada Gambar 10. Pada temperatur minimum, efisiensi refrigerasi sistem yang menggunakan R404A dan R507A memiliki nilai yang sama besar, dan nilainya lebih kecil dari R290 dan R600a masing-masingnya $\pm 12,31 \%$ dan $\pm 14,39 \%$. Temperatur evaporasi memiliki pengaruh yang kuat terhadap efisiensi refrigerasi.

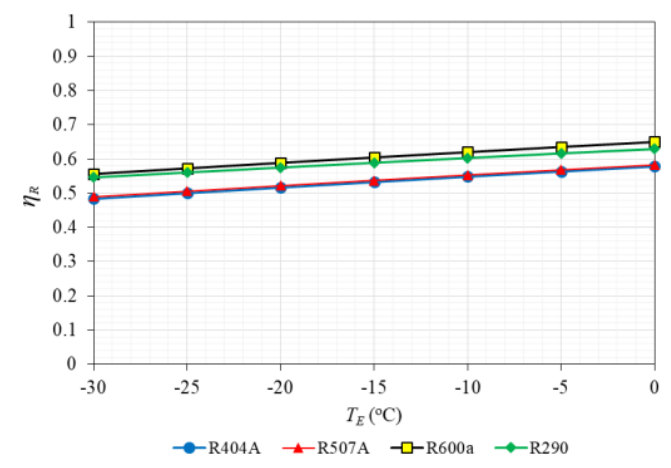

Gambar 11Temperatur evaporasi vs efisiensi pendinginan 


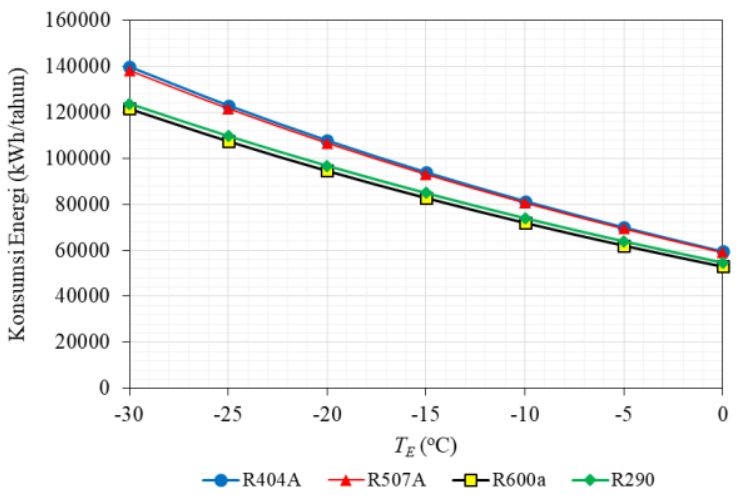

\section{Gambar 12 Temperatur evaporasi vs konsumsi energi}

Konsumsi energi sistem selama satu tahun pengoperasian yang menggunakan R404A dan R507A memiliki nilai yang lebih besar daripada yang menggunakan R290 dan R600a. Hal ini ditunjukkan dalam Gambar 11, di mana terlihat bahwa R600a memiliki nilai konsumsi energi yang paling rendah, dan lebih rendah $\pm 1,85 \%$ dibandingkan dengan penggunaan R290 pada temperatur evaporasi minimum.

Sebagai tambahan informasi dalam analisis ini disajikan pengaruh temperatur evaporasi terhadap volume hisap dan volume buang refrigeran selama proses refrigerasi. Pada Gambar 12 terlihat bahwa dengan menurunnya temperatur evaporasi maka volume hisap kompresor akan meningkat. Pada temperatur evaporasi minimum, penggunaan R600a memiliki volume hisap yang sangat jauh lebih besar dibandingkan dengan ketiga refrigeran lainnya. Penggunaan R290 memiliki volume hisap lebih besar $\pm 8,12 \%$ dibandingkan dengan R404A, dan lebih besar $\pm 14,16 \%$ daripada R507A.

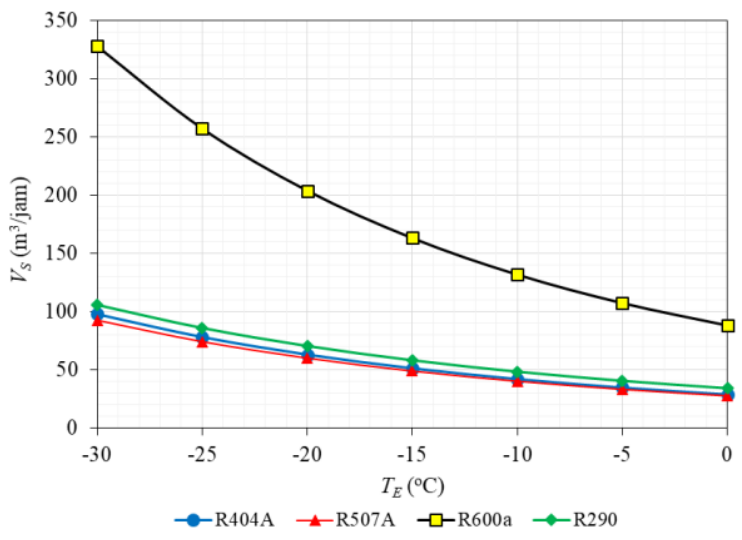

Gambar 13 Temperatur evaporasi vs volume hisap kompresor

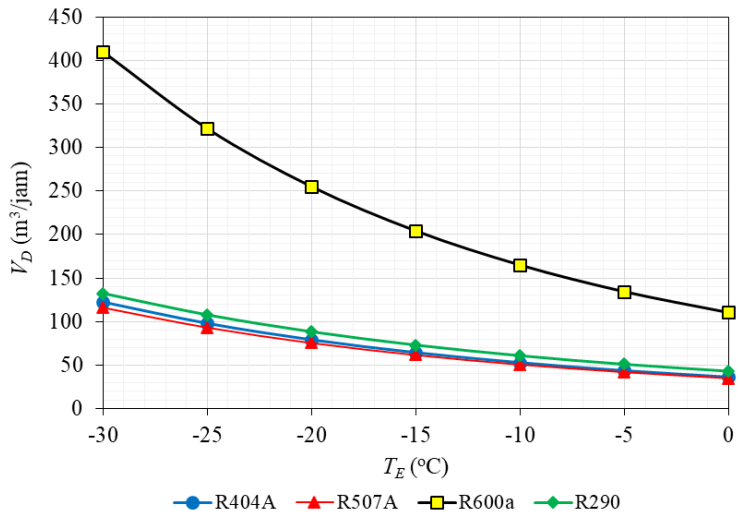

\section{Gambar 14 Temperatur evaporasi vs volume buang kompresor}

Sama seperti volume hisap, untuk volume buang menunjukkan kecenderungan yang sama, yaitu penggunaan R600a memiliki volume buang yang jauh lebih besar dibandingkan dengan ketiga refrigeran lainnya. Penggunaan R290 memiliki volume buang lebih besar $\pm 8,16 \%$ daripada R404A, dan lebih besar $\pm 14,22 \%$ dibandingkan dengan penggunaan R507A. Karena volume hisap dan buang R290 memiliki nilai yang lebih dekat dengan R404A dan R507A, maka dimensi kompresor ketiga refrigeran tersebut memiliki ukuran yang tidak jauh berbeda.

\section{KESIMPULAN}

Secara prinsip studi teoritis ini menunjukkan bahwa penggunaan refrigeran hidrokarbon (R290 dan R600a) akan menghasilkan kinerja sistem yang lebih baik dibandingkan dengan penggunaan refrigeran hidrofluorokebon (R404A dan R507A).

Pada temperatur evaporator minimum ($30^{\circ} \mathrm{C}$ ) sistem yang menggunakan R290 dan R600a memiliki COP, dan efisiensi refrigerasi rata-rata lebih tinggi $\pm 14 \%$ serta konsumsi energi yang lebih rendah dibandingkan dengan penggunaan R404A dan R507A.

R290 memiliki karakteristik yang lebih dekat pada R404A dan R507A sehingga lebih sesuai menggantikan kedua refrigeran tersebut dibandingkan dengan R600a. Di samping itu, refrigeran hidrokarbon lebih ramah lingkungan dibandingkan refrigeran hidrofluorokarbon sehingga penggunaannya pada masa yang akan datang lebih dianjurkan, walaupun memiliki sifat lebih mudah terbakar. 


\section{DAFTAR PUSTAKA}

[1] Anonim, Buku Manual Cold Storage Kapasitas 100T DKP Kupang, Kementerian Kelautan dan Perikanan, Republik Indonesia, 2017, pp. 11-12, 27.

[2] El-Sayed A. R., El-Morsi M., and Mahmoud N A., A Review of the Potential Replacements of HCFC/HFCs Using Environmental Friendly Refrigerants, International Journal of AirConditioning and Refrigeration, Vol. 26, No. 3, 2018, pp. 1-24.

[3] Bhatkar V. W., Kriplani V. M., and Awari, G. K., Alternative Refrigerants in Vapour Compression Refrigeration Cycle for Sustainable Environment: A Review of Recent Research, International Journal of Environmental Science and Technology, Vol. 10, 2013, pp. 871-880.

[4] Dwinanto M. M., Koehuan V. A., and Monteiro J. M., Analysis of Dual Evaporator Refrigeration System via Exergetic Performance Coefficient Criterion, Prosiding SEMNASTEK, 2015, hal. 1-17.

[5] Dwinanto M. M., Suhanan, and Prajitno, Exergy Analysis of a Dual-Evaporator Refrigeration Systems, AIP Conference Proceedings, 1788, 2017, pp. 030011:1-8.

[6] Shiliday, J. A., Tassou, S. A., and Shiliday, N., 2009, Comparative Energy and Exergy Analysis of R744, R404A and R290 Refrigeration Cycles, International Journal of Low-Carbon Technologies, 2009, 00: 1-8.

[7] Bukola O. B., and Zhongjie H., Comparative Analysis of the Performance of Hydrocarbon
Refrigerants with R22 in A Sub-Cooling Heat Exchanger Refrigeration System, Journal of Power and Energy, Vol. 226, No. 7, 2012, pp. 882-891.

[8] Rasti M., Aghamiri S. F., and Hatamipour M. S., Energy efficiency enhancement of a domestic refrigerator using R436A and R600a as alternative refrigerants to R134a, International Journal of Thermal Sciences, Vol. 74, 2013, pp. 86-94.

[9] Venkataiah S., and Rao G. V., Analysis of Alternative Refrigerants to R22 for AirConditioning Applications at Various Evaporating Temperatures, International Journal of Engineering Research and Applications, Vol. 4, No. 3, 2014, pp. 39-46.

[10] Prayudi, Nurhasanah R., and Diantari R. A., 2017, "The Effect the Effectiveness of the Liquid Suction Heat Exchanger to Performance of Cold Storage with Refrigerant R22, R404A and R290/R600a", AIP Conference Proceedings, 1788, 2017, pp. 030067:1-8.

[11] Jakobsen A, Rasmussen B. D., Skovrup M. J., and Andersen, S. E., CoolPack-A Collection of Simulation Tools for Refrigeration, Department of Energy Engineering, Technical University of Denmark (DTU), Denmark, 2001.

[12] Sencan A., Selbas R., Kizilkan O., and Kalogiru S. A., Thermodynamic analysis of subcooling and superheating effects of alternative refrigerants for vapour compression refrigeration cycles", International Journal of Energy Research, Vol. 30, 2006, pp. 323-347. 